Brazilian Journal
of Chemical
Engineering

ISSN 0104-6632

Printed in Brazil

www.abeq.org.br/bjche

Vol. 28, No. 01, pp. 27 - 36, January - March, 2011

\title{
LACTIC ACID PRODUCTION BY NEW Lactobacillus plantarum LMISM6 GROWN IN MOLASSES: OPTIMIZATION OF MEDIUM COMPOSITION
}

\author{
L. F. Coelho ${ }^{1}$, C. J. B. de Lima ${ }^{1}$, C. M. Rodovalho ${ }^{2}$, M. P. Bernardo ${ }^{1}$ and J. Contiero ${ }^{1 *}$ \\ ${ }^{1}$ Department of Biochemistry and Microbiology, Institute of Biological Sciences, \\ Phone: + (55) (19) 3526-4180, Fax: + (55) (19) 3526-4176, Universidade Estadual Paulista, \\ (UNESP), Zip Code 13506-900, Rio Claro - SP, Brazil. \\ E-mail: jconti@rc.unesp.br \\ ${ }^{2}$ Department of Biology, Institute of Biological Sciences, Universidade Estadual Paulista, \\ (UNESP), Zip Code 13506-900, Rio Claro - SP, Brazil.
}

(Submitted: March 12, 2010 ; Revised: September 10, 2010 ; Accepted: September 27, 2010)

\begin{abstract}
A Plackett-Burman experimental design was used to evaluate seven medium components added to molasses (corn steep liquor, sodium acetate, magnesium sulfate, manganese sulfate, ammonium citrate, potassium phosphate and Tween 80). Corn steep liquor (CSL), $\mathrm{K}_{2} \mathrm{HPO}_{4}$ and Tween 80 increased lactic acid production. The concentrations of these three components as well as the molasses were further optimized using the response surface method. A maximal lactic acid production of $94.8 \mathrm{~g} \mathrm{~L}^{-1}$ was obtained when the concentrations of molasses, CSL, $\mathrm{K}_{2} \mathrm{HPO}_{4}$ and Tween 80 were $193.50 \mathrm{~g} \mathrm{~L}^{-1}, 37.50 \mathrm{~mL} \mathrm{~L}^{-1}, 2.65 \mathrm{~g} \mathrm{~L}^{-1}$ and $0.83 \mathrm{~mL} \mathrm{~L}^{-1}$, respectively. However, in both shaker and bioreactor, approximately one fourth of the sugar added initially was not utilized after 48 hours of fermentation. Future studies that consider high conversion of sugar into final product as well as high volumetric productivity are necessary to improve the fermentation process and to reduce the downstream costs.

Keywords: Plackett-Burman; Corn steep liquor; Response surface methodology; Medium optimization; Potassium phosphate; Tween.
\end{abstract}

\section{INTRODUCTION}

Lactic acid is an organic acid with a wide range of applications in the food, pharmaceutical and cosmetics industries (Datta et al., 1995). It has recently been studied with great interest as a biodegradable polylactic acid (PLA) that can be used to improve physical properties in the production of food packaging, plastic utensils, garbage bags and agricultural plastic sheeting, thereby replacing products made from petroleum (Ohara, 2003).

Lactic acid can be obtained either by the action of fermentative microorganisms or chemical synthesis.
The fermentation process has the advantage of being more cost effective (Silva and Mancilha, 1991). Approximately $90 \%$ of all lactic acid worldwide is produced by bacterial fermentation (Zhou et al., 2006).

Lactic acid bacteria are traditionally fastidious microorganisms and have complex nutrient requirements due to their limited ability to biosynthesize B-vitamins and amino acids (Fitzpatrick and Keeffe, 2001).

Refined sugars, such as glucose or sucrose, have been used more frequently as a carbon source to produce lactic acid than raw starchy substrates, such

*To whom correspondence should be addressed 
as barley, corn, or wheat (Hofvendahl and HahnHägerdal, 1997). Furthermore, a considerable amount of an expensive complex nitrogen source, such as yeast extract, must be added to the medium in order to produce lactic acid within a reasonable timeframe. However, this is economically unfavorable. According to Tejayadi and Cheryan (1995), raw materials account for $68 \%$ of the overall cost of lactic acid production from whey and yeast extract using Lactobacillus bulgaricus.

A number of industrial by-products or wastes have been evaluated as substrates for lactic acid production with the aim of decreasing the cost of the process, such as sugarcane (Calabia and Tokiwa, 2007), molasses (Dumbrepatil et al., 2008) and whey (Buyukkileci and Harsa, 2004) as carbon sources and CSL (Bustos et al., 2004) as a nitrogen source. CSL is an excellent source of nitrogen for most microorganisms due to its high concentration of amino acids and polypeptides, with considerable amounts of B-complex vitamins (Cardinal and Hedrick, 1948). Sugarcane molasses is an industrial by-product of sugar and alcohol processing and is rich in fermentable sugars (Lima et al., 1975), nitrogen and vitamins. This substrate is inexpensive and highly available in Brazil, with an annual production of 17.9 million tons during the sugar manufacturing process.

The aim of the present study was to optimize lactic acid production by Lactobacillus plantarum LMISM6 grown in molasses.

\section{MATERIALS AND METHODS}

\section{Microorganism}

Lactobacillus plantarum LMISM6 was isolated from cassava wastewater. The stock cultures were maintained in Man, Rogosa and Sharpe (MRS) growth medium with $20 \%(\mathrm{v} / \mathrm{v})$ glycerol at $-20{ }^{\circ} \mathrm{C}$. The MRS medium had the following composition $\left(\mathrm{g} \mathrm{L}^{-1}\right)$ : glucose $(20.0)$, peptone $(10.0)$, yeast extract (5.0), meat extract (10.0), sodium acetate (5.0), ammonium citrate (2.0), $\mathrm{K}_{2} \mathrm{HPO}_{4} \quad$ (5.0), $\mathrm{MgSO}_{4} .7 \mathrm{H}_{2} \mathrm{O}(0.1)$ and $\mathrm{MnSO}_{4} \cdot 4 \mathrm{H}_{2} \mathrm{O}(0.05)$. The $\mathrm{pH}$ was adjusted to 6.0 prior to sterilization at $121^{\circ} \mathrm{C}$ for $15 \mathrm{~min}$.

\section{Inoculum Preparation}

The inoculum was prepared through the transference of $2 \%$ of stock culture to Erlenmeyer flasks containing growth medium (MRS). Incubation temperature was $35 \pm 1^{\circ} \mathrm{C}$ for 18 hours at $150 \mathrm{rpm}$.

\section{Substrate}

The cane molasses was obtained from the Santa Lucia plant located in Araras-SP, Brazil and this substrate was hydrolyzed by adding $1 \mathrm{ml}$ of $\mathrm{H}_{2} \mathrm{SO}_{4}$ $(20 \%)$ to $100 \mathrm{ml}$ of molasses solution. The acidified molasses solution was heated in a boiling water bath for $20 \mathrm{~min}$. The $\mathrm{pH}$ of the medium was adjusted to 6.0 with $4.0 \mathrm{M} \mathrm{KOH}$ prior to sterilization. The sugarcane molasses contained $100 \%$ reducing sugar.

\section{Analysis}

Lactic acid concentrations were determined by a high performance liquid chromatography system equipped with a UV detector at $210 \mathrm{~nm}$. A Rezex ROA (300 x $7.8 \mathrm{~mm}$, Phenomenex) column was eluted with $5 \mathrm{mM} \mathrm{H}_{2} \mathrm{SO}_{4}$ as the mobile phase at a flow rate of $0.4 \mathrm{~mL} / \mathrm{min}$ and the column temperature was maintained at $60^{\circ} \mathrm{C}$. Reducing sugars were measured using the 3.5-dinitrosalicylic acid method (Miller, 1959). Cell growth was determined using a spectrophotometer at $650 \mathrm{~nm}$ (OD650) following centrifugation and washing of the cells. The dry mass was determined from a standard curve of optical density versus dry mass.

\section{Plackett-Burman Experimental Design}

The purpose of this first step of the optimization was to identify the medium components with a significant effect on lactic acid production by Lactobacillus plantarum LMISM6 using molasses. The sugar concentration from molasses was maintained constant $\left(150 \mathrm{~g} \quad \mathrm{~L}^{-1}\right)$ and twelve experiments were generated from seven factors: CSL, sodium acetate, magnesium sulfate, manganese sulfate, ammonium citrate, potassium phosphate and Tween 80 . The variables with a confidence level greater than $95 \%$ were considered to have a significant influence on lactic acid production. The Plackett-Burman experimental design (PB) was based on the first-order model, with no interaction among the factors (Plackett and Burman, 1946). The concentrations used for each variable are displayed in Table 1.

The experiments were done in $125 \mathrm{~mL}$ Erlenmeyer flasks containing $20 \mathrm{~mL}$ of production medium and $100 \mathrm{~g} \mathrm{~L}^{-1}$ of calcium carbonate at 150 rpm for $48 \mathrm{~h}$. 
A central composite design (CCD) was performed with the variables that significantly increased the production of lactic acid.

Table 1: Variables and levels used in PlackettBurman design

\begin{tabular}{|l|c|c|r|}
\hline \multirow{2}{*}{ Variables } & \multirow{2}{*}{ Codes } & \multicolumn{2}{|c|}{ Range and levels } \\
\cline { 3 - 4 } & & $\mathbf{- 1}$ & $+\mathbf{1}$ \\
\hline Sodium acetate $\left(\mathrm{g} \mathrm{L}^{-1}\right)$ & $\mathrm{X}_{1}$ & 0 & 5 \\
$\mathrm{MgSO}_{4}\left(\mathrm{~g} \mathrm{~L}^{-1}\right)$ & $\mathrm{X}_{2}$ & 0 & 0.2 \\
$\mathrm{MnSO}_{4}\left(\mathrm{~g} \mathrm{~L}^{-1}\right)$ & $\mathrm{X}_{3}$ & 0 & 0.1 \\
${\text { Citrate }\left(\mathrm{g} \mathrm{L}^{-1}\right)}_{\mathrm{X}_{4}}$ & 0 & 2 \\
$\mathrm{~K}_{2} \mathrm{HPO}_{4}\left(\mathrm{~g} \mathrm{~L}^{-1}\right)$ & $\mathrm{X}_{5}$ & 0 & 2 \\
Tween $80\left(\mathrm{~mL} \mathrm{~L}^{-1}\right)$ & $\mathrm{X}_{6}$ & 0 & 1 \\
$\mathrm{CSL}\left(\mathrm{mL} \mathrm{L}^{-1}\right)$ & $\mathrm{X}_{7}$ & 0 & 70 \\
\hline
\end{tabular}

\section{Central Composite Design and Optimization Using} Response Surface Methodology

A central composite design (CCD) with four independent variables - each at five levels with eight star points $(\alpha=2.0)$ and four replicates at the center points - was used to develop a second-order polynomial model that determined the optimal values of variables for lactic acid production. Screened through previous work, CSL, $\mathrm{K}_{2} \mathrm{HPO}_{4}$ and Tween 80 were taken as variables for investigation, along with molasses.

The variables of the experiments were coded according to the following equation:

$\mathrm{x}_{\mathrm{i}}=\left(\mathrm{X}_{\mathrm{i}}-\mathrm{X}_{\mathrm{CP}}\right) / \Delta \mathrm{X}_{\mathrm{i}}$

in which $x_{i}$ is the coded value of an independent variable; $X_{i}$ is the real value of an independent variable; $X_{C P}$ is the real value of an independent variable at the center point; and $\Delta \mathrm{X}_{i}$ is the step change value.

The behavior of the system was described by the following quadratic equation:

$$
\mathrm{Y}=\mathrm{b}_{0}+\sum \mathrm{b}_{\mathrm{i}} \mathrm{x}_{\mathrm{i}}+\sum \mathrm{b}_{\mathrm{ii}} \mathrm{x}_{\mathrm{i}}^{2}+\sum \mathrm{b}_{\mathrm{ij}} \mathrm{x}_{\mathrm{i}} \mathrm{x}_{\mathrm{j}}
$$

in which $\mathrm{Y}$ is the predicted response, i.e., lactic acid concentration; $b_{0}$ is the offset term; $b_{i}$ is the linear effect; $b_{i i}$ is the squared effect; $b_{i j}$ is the interaction effect; and $x_{i}$ is the independent variable.

Using the CCD method, a total of 28 experiments with various combinations of molasses, CSL, $\mathrm{K}_{2} \mathrm{HPO}_{4}$ and Tween 80 were conducted. Table 2 displays the range and levels of the variables investigated.

The experiments were done in $125 \mathrm{~mL}$ Erlenmeyer flasks containing $20 \mathrm{~mL}$ of production medium and $100 \mathrm{~g} \mathrm{~L}^{-1}$ of calcium carbonate at 150 rpm for $48 \mathrm{~h}$.

Table 2: Real values of variables used in central composite design

\begin{tabular}{|c|c|c|c|c|c|c|}
\hline \multirow{2}{*}{ Variables } & \multirow{2}{*}{ Codes } & \multicolumn{5}{|c|}{ Ranges and levels } \\
\hline & & -2 & -1 & $\mathbf{0}$ & +1 & +2 \\
\hline Molasses $\left(\mathrm{g} \mathrm{L}^{-1}\right)$ & $\overline{X_{1}}$ & 70 & 120 & 170 & 220 & 270 \\
\hline $\operatorname{CSL}\left(\mathrm{mL} \mathrm{L}^{-1}\right)^{\mathrm{a}}$ & $\mathrm{X}_{2}$ & 0 & 15 & 30 & 45 & 60 \\
\hline $\mathrm{K}_{2} \mathrm{HPO}_{4}\left(\mathrm{~mL} \mathrm{~L}^{-1}\right)^{\mathrm{a}}$ & $X_{3}$ & 0 & 1.0 & 2.0 & 3.0 & 4.0 \\
\hline Tween $80\left(\mathrm{~g} \mathrm{~L}^{-1}\right)^{\mathrm{a}}$ & $\mathrm{X}_{4}$ & 0 & 0.5 & 1.0 & 1.5 & 2.0 \\
\hline
\end{tabular}

${ }^{a}$ Variables identified as significant in increasing the lactic

acid production using a Plackett-Burman design

The Statistica 7.0 software package (StatSoft, Tulsa, USA) was used for the experimental design and regression analysis of the experimental data. The response surface was generated to understand the interactions among the variables. The optimal points for the variables were obtained from Maple 9.5 (Waterloo Maple Inc., Ontario, Canada).

In order to validate the optimization of the medium composition, tests were carried out using the optimized condition to confirm the results of the response surface analysis.

\section{Scale-Up Fermentation of Lactic Acid Production}

Scale-up fermentation of lactic acid production with the optimal medium was carried out in a $13 \mathrm{~L}$ glass vase bioreactor with an initial medium volume of $4.0 \mathrm{~L}$. Agitation speed and culture temperature were controlled at $150 \mathrm{rpm}$ and $35^{\circ} \mathrm{C}$, respectively. The $\mathrm{pH}$ was controlled at 6.0 by the automatic addition of $10 \mathrm{M} \mathrm{NaOH}$. Samples of $1 \mathrm{~mL}$ were withdrawn from the fermentation broth every 3 hours for 96 hours and centrifuged at 7,800 $\mathrm{g}$ for 10 minutes.

\section{RESULTS AND DISCUSSION}

\section{Plackett-Burman Experimental Design}

Table 3 displays the Plackett-Burman design matrix (real and coded values) of the 12 experiments with seven variables added to molasses $\left(\mathrm{X}_{1}=\right.$ Acetate, $\quad \mathrm{X}_{2}=\mathrm{MgSO}_{4}, \quad \mathrm{X}_{3}=\mathrm{MnSO}_{4}, \quad \mathrm{X}_{4}=$ Citrate, $\mathrm{X}_{5}=\mathrm{K}_{2} \mathrm{HPO}_{4}, \mathrm{X}_{6}=$ Tween $80, \mathrm{X}_{7}=\mathrm{CSL}$ ) and the respective results (lactic acid).

CSL was the most influential variable in the production of lactic acid, followed by $\mathrm{K}_{2} \mathrm{HPO}_{4}$ and Tween 80. All three variables had a significant positive effect on lactic acid production at a $95 \%$ 
confidence level. Figure 1 (Pareto chart) illustrates the effects of these variables, which were therefore used to optimize the production of lactic acid.

$\mathrm{K}_{2} \mathrm{HPO}_{4}$ had a positive effect on lactic acid production (Fig. 1). According to Honorato et al. (2007), the addition of phosphate to the culture medium increases the growth of the microorganism and enhances lactic acid production, as this component maintains the $\mathrm{pH}$ near the optimal growth value, thereby allowing the conduction of fermentation for a longer time.

The Plackett-Burman design is a two-level multifactorial design based on the rationale known as balanced incomplete blocks (Stanbury et al., 1986). The key to this technique is forming various combinations (which are called assemblies) of the components with varying amounts. Plackett-Burman design is an efficient way to screen for the important factors among a large number of variables. As there were seven parameters to be evaluated for lactic acid production, the Plackett-Burman was the most appropriate design.

There are a number of reports in which the Plackett-Burman design has been used to screen the factors in a fermentation medium to be optimized in subsequent experiments (Krishnan et al., 1998; Reddy et al., 1999; Son et al., 1998; Srinivas et al., 1994; Yu et al., 1997).

After finding the critical factors $\left(\mathrm{CSL}, \mathrm{K}_{2} \mathrm{HPO}_{4}\right.$ and Tween 80), the next step was to optimize the concentrations of these components in the growth medium. In this work, a response surface methodology (RSM) using a central composite design was used.

Table 3: Plackett-Burman design (real and coded values) with the respective results

\begin{tabular}{|c|c|c|c|c|c|c|c|c|}
\hline \multirow{2}{*}{ Run } & \multicolumn{7}{|c|}{ Independent variables $^{\mathbf{a}}$} & \multicolumn{1}{c|}{ Response } \\
\cline { 2 - 8 } & $\mathbf{X}_{\mathbf{1}}$ & $\mathbf{X}_{\mathbf{2}}$ & $\mathbf{X}_{\mathbf{3}}$ & \multicolumn{1}{|c|}{$\mathbf{X}_{\mathbf{4}}$} & \multicolumn{1}{|c|}{$\mathbf{X}_{\mathbf{5}}$} & $\mathbf{X}_{\mathbf{6}}$ & $\mathbf{X}_{\mathbf{7}}$ & Lactic acid (g L $^{-1}$ ) \\
\hline 1 & $5(1)^{\mathrm{b}}$ & $0(-1)$ & $0.1(1)$ & $0(-1)$ & $0(-1)$ & $0(-1)$ & $70(1)$ & 78.64 \\
2 & $5(1)$ & $0.2(1)$ & $0(-1)$ & $2(1)$ & $0(-1)$ & $0(-1)$ & $0(-1)$ & 5.44 \\
3 & $0(-1)$ & $0.2(1)$ & $0.1(1)$ & $0(-1)$ & $2(1)$ & $0(-1)$ & $0(-1)$ & 17.92 \\
4 & $5(1)$ & $0(-1)$ & $0.1(1)$ & $2(1)$ & $0(-1)$ & $1(1)$ & $0(-1)$ & 13.96 \\
5 & $5(1)$ & $0.2(1)$ & $0(-1)$ & $2(1)$ & $2(1)$ & $0(-1)$ & $70(1)$ & 85.04 \\
6 & $5(1)$ & $0.2(1)$ & $0.1(1)$ & $0(-1)$ & $2(1)$ & $1(1)$ & $0(-1)$ & 42.64 \\
7 & $0(-1)$ & $0.2(1)$ & $0.1(1)$ & $2(1)$ & $0(-1)$ & $1(1)$ & $70(1)$ & 82.40 \\
8 & $0(-1)$ & $0(-1)$ & $0.1(1)$ & $2(1)$ & $2(1)$ & $0(-1)$ & $70(1)$ & 81.32 \\
9 & $0(-1)$ & $0(-1)$ & $0(-1)$ & $2(1)$ & $2(1)$ & $1(1)$ & $0(-1)$ & 40.64 \\
10 & $5(1)$ & $0(-1)$ & $0(-1)$ & $0(-1)$ & $2(1)$ & $1(1)$ & $70(1)$ & 96.48 \\
11 & $0(-1)$ & $0.2(1)$ & $0(-1)$ & $0(-1)$ & $0(-1)$ & $1(1)$ & $70(1)$ & 85.20 \\
12 & $0(-1)$ & $0(-1)$ & $0(-1)$ & $0(-1)$ & $0(-1)$ & $0(-1)$ & $0(-1)$ & 6.00 \\
\hline
\end{tabular}

${ }^{a} \mathrm{X}_{1}=$ Acetate, $\mathrm{X}_{2}=\mathrm{MgSO}_{4}, \mathrm{X}_{3}=\mathrm{MnSO}_{4}, \mathrm{X}_{4}=$ Citrate, $\mathrm{X}_{5}=\mathrm{K}_{2} \mathrm{HPO}_{4}, \mathrm{X}_{6}=$ Tween $80, \mathrm{X}_{7}=\mathrm{CSL}$

${ }^{\mathrm{b}}(-1)$ and (1) are coded levels.

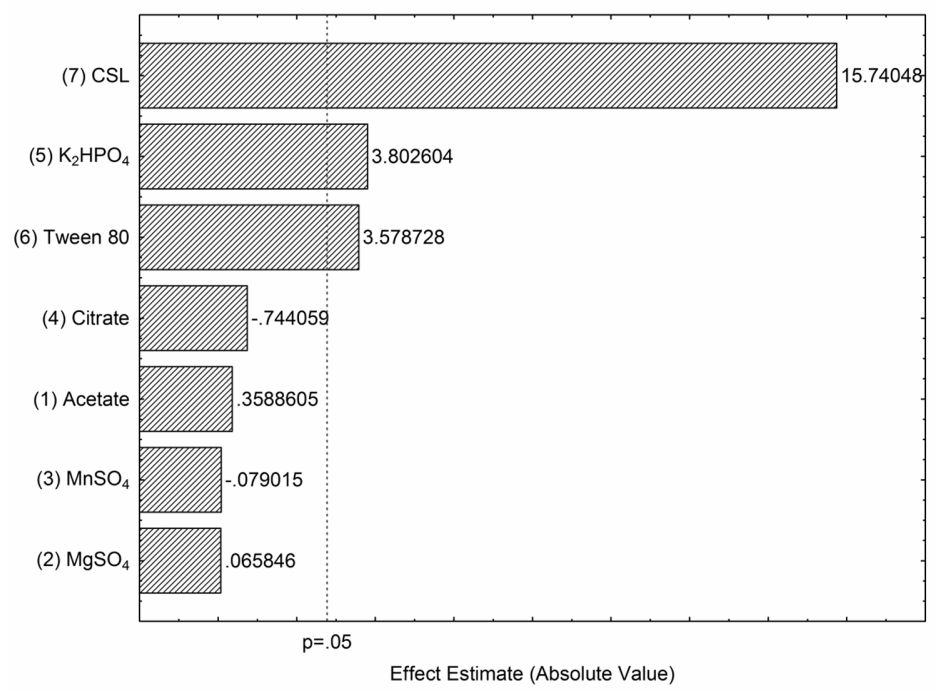

Figure 1: Pareto chart for lactic acid production 


\section{Response Surface Methodology}

The three above-mentioned components and molasses were further optimized using response surface optimization. Table 4 displays the design matrix of the variables in coded units and real values with the respective results.

The highest production of lactic acid was $90.2 \mathrm{~g} \mathrm{~L}^{-1}$, obtained from $220 \mathrm{~g} \mathrm{~L}^{-1}$ of molasses, $45 \mathrm{~mL} \mathrm{~L}^{-1}$ of CSL, $3 \mathrm{~g} \mathrm{~L}^{-1}$ of $\mathrm{K}_{2} \mathrm{HPO}_{4}$ and $1.5 \mathrm{~mL} \mathrm{~L}^{-1}$ of Tween 80 (Table 4). The application of multiple regression analysis methods yielded the following regression Eq. (3) for the experimental data.

$$
\begin{aligned}
& Y=85.5+3.91 X_{1}+8.19 X_{2}+4.38 X_{3}+ \\
& 2.69 X_{4}-3.58 X_{1}^{2}-6.42 X_{2}^{2}-3.38 X_{3}^{2}- \\
& 0.96 X_{4}^{2}-1.8 X_{1} X_{2}-0.39 X_{1} X_{3}+0.44 X_{1} X_{4}- \\
& 0.19 X_{2} X_{3}-0.51 X_{2} X_{4}+0.25 X_{3} X_{4}
\end{aligned}
$$

The quadratic model in Equation (3) contains four linear terms, four quadratic terms and six factorial interactions, in which $\mathrm{Y}$ is the predicted response (lactic acid concentration) and $\mathrm{X}_{1}, \mathrm{X}_{2}, \mathrm{X}_{3}$ and $\mathrm{X}_{4}$ are the coded values of molasses, CSL, $\mathrm{K}_{2} \mathrm{HPO}_{4}$ and
Tween 80 , respectively.

Table 5 displays the Student's t-distribution and the probability $(p)$ values that serve as a tool to check the significance of each coefficient. Smaller $p$-values denote a more significant corresponding coefficient.

The results show that the variables $\mathrm{X}_{1}$ (molasses), $\mathrm{X}_{2}(\mathrm{CSL}), \mathrm{X}_{3}\left(\mathrm{~K}_{2} \mathrm{HPO}_{4}\right)$ and $\mathrm{X}_{4}$ (Tween 80) had a significant effect, based on $p$-values lower than 0.05 . Moreover, as these variables have positive coefficients (Table 5), an increase in their concentrations results in an increase in the production yield. The squared variables $\mathrm{X}_{1}^{2}, \mathrm{X}_{2}^{2}$, $\mathrm{X}_{3}^{2}, \mathrm{X}_{4}^{2}$ and the $\mathrm{X}_{1} \mathrm{X}_{2}$ interaction were also significant to different extents. The non-significant terms $\left(\mathrm{X}_{1} \mathrm{X}_{3}, \mathrm{X}_{1} \mathrm{X}_{4}, \mathrm{X}_{2} \mathrm{X}_{3}, \mathrm{X}_{2} \mathrm{X}_{4}, \mathrm{X}_{3} \mathrm{X}_{4}\right)$ were discarded. The Eq. (3) model was modified to the reduced Eq. (4) fitted model.

$$
\begin{aligned}
& \mathrm{Y}=85.55+3.9 \mathrm{X}_{1}+8.19 \mathrm{X}_{2}+4.38 \mathrm{X}_{3}+2.68 \mathrm{X}_{4}- \\
& 3.85 \mathrm{X}_{1}^{2}-1.8 \mathrm{X}_{1} \mathrm{X}_{2}-6.42 \mathrm{X}_{2}^{2}-3.38 \mathrm{X}_{3}^{2}-0.95 \mathrm{X}_{4}^{2}
\end{aligned}
$$

The response surface quadratic model was

\begin{tabular}{|c|c|c|c|c|c|}
\hline \multirow{2}{*}{ Run } & \multicolumn{4}{|c|}{ Independent variables } & \multirow{2}{*}{$\begin{array}{c}\text { Response } \\
\text { Lactic acid }\left(\mathrm{g} \mathrm{L}^{-1}\right)\end{array}$} \\
\hline & $\mathbf{X}_{1}$ & $\mathbf{X}_{2}$ & $\mathbf{X}_{3}$ & $\mathbf{X}_{4}$ & \\
\hline 1 & $120(-1)^{\mathrm{a}}$ & $15(-1)$ & $1(-1)$ & $0.5(-1)$ & 48.9 \\
\hline 2 & $120(-1)$ & $15(-1)$ & $1(-1)$ & $1.5(1)$ & 54.9 \\
\hline 3 & $120(-1)$ & $15(-1)$ & $3(1)$ & $0.5(-1)$ & 59.8 \\
\hline 4 & $120(-1)$ & $15(-1)$ & $3(1)$ & $1.5(1)$ & 66 \\
\hline 5 & $120(-1)$ & $45(1)$ & $1(-1)$ & $0.5(-1)$ & 71.4 \\
\hline 6 & $120(-1)$ & $45(1)$ & $1(-1)$ & $1.5(1)$ & 75 \\
\hline 7 & $120(-1)$ & $45(1)$ & $3(1)$ & $0.5(-1)$ & 80 \\
\hline 8 & $120(-1)$ & $45(1)$ & $3(1)$ & $1.5(1)$ & 83 \\
\hline 9 & $220(1)$ & $15(-1)$ & $1(-1)$ & $0.5(-1)$ & 61.6 \\
\hline 10 & $220(1)$ & $15(-1)$ & $1(-1)$ & $1.5(1)$ & 68.9 \\
\hline 11 & $220(1)$ & $15(-1)$ & $3(1)$ & $0.5(-1)$ & 69.3 \\
\hline 12 & $220(1)$ & $15(-1)$ & $3(1)$ & $1.5(1)$ & 76.3 \\
\hline 13 & $220(1)$ & $45(1)$ & $1(-1)$ & $0.5(-1)$ & 75.7 \\
\hline 14 & $220(1)$ & $45(1)$ & $1(-1)$ & $1.5(1)$ & 79.15 \\
\hline 15 & $220(1)$ & $45(1)$ & $3(1)$ & $0.5(-1)$ & 82 \\
\hline 16 & $220(1)$ & $45(1)$ & $3(1)$ & $1.5(1)$ & 90.2 \\
\hline 17 & $70(-2)$ & $30(0)$ & $2(0)$ & $1(0)$ & 63.4 \\
\hline 18 & $270(2)$ & $30(0)$ & $2(0)$ & $1(0)$ & 78.3 \\
\hline 19 & $170(0)$ & $0(-2)$ & $2(0)$ & $1(0)$ & 43 \\
\hline 20 & $170(0)$ & $60(2)$ & $2(0)$ & $1(0)$ & 76 \\
\hline 21 & $170(0)$ & $30(0)$ & $0(-2)$ & $1(0)$ & 63.1 \\
\hline 22 & $170(0)$ & $30(0)$ & $4(2)$ & $1(0)$ & 80.2 \\
\hline 23 & $170(0)$ & $30(0)$ & $2(0)$ & $0(-2)$ & 76.4 \\
\hline 24 & $170(0)$ & $30(0)$ & $2(0)$ & $2(2)$ & 86.3 \\
\hline 25 & $170(0)$ & $30(0)$ & $2(0)$ & $1(0)$ & 85.2 \\
\hline 26 & $170(0)$ & $30(0)$ & $2(0)$ & $1(0)$ & 86 \\
\hline 27 & $170(0)$ & $30(0)$ & $2(0)$ & $1(0)$ & 85.1 \\
\hline 28 & $170(0)$ & $30(0)$ & $2(0)$ & $1(0)$ & 85.9 \\
\hline
\end{tabular}
performed in the form of analysis of variance (ANOVA) and the results are summarized in Table 6. The $F$-test was used to check the statistical significance of Eq. (4).

Table 4: Central composite design and results

${ }^{\mathrm{a}}(-2),(-1),(0),(1)$ and $(2)$ are coded levels. 
Table 5: Coefficients of t-values for lactic acid production using a composite rotatable design

\begin{tabular}{|c|c|c|c|c|}
\hline Factor & Coefficient & Standard error coefficient & $\boldsymbol{t}$-value & Probability \\
\hline Intercept & 85.55000 & 0.487286 & 175.5641 & 0.000000 \\
$\mathrm{X}_{1}$ & 3.91458 & 0.198934 & 19.6778 & 0.000000 \\
$\mathrm{X}_{2}$ & 8.19792 & 0.198934 & 41.2093 & 0.000000 \\
$\mathrm{X}_{3}$ & 4.38542 & 0.198934 & 22.0446 & 0.000000 \\
$\mathrm{X}_{4}$ & 2.68958 & 0.198934 & 13.5200 & 0.000000 \\
$\mathrm{X}_{1} \mathrm{X}_{1} \mathrm{X}_{2}$ & -3.58385 & 0.198934 & -18.0153 & 0.000000 \\
$\mathrm{X}_{1} \mathrm{X}_{3}$ & -1.80313 & 0.243643 & -7.4007 & 0.000005 \\
$\mathrm{X}_{1} \mathrm{X}_{4}$ & -0.38438 & -1.5776 & 0.138669 \\
$\mathrm{X}_{2}{ }_{\mathrm{X}_{2} \mathrm{X}_{3}}$ & 0.44688 & 0.243643 & 1.8341 & 0.089618 \\
$\mathrm{X}_{2} \mathrm{X}_{4}$ & -6.42135 & 0.243643 & -32.2789 & 0.000000 \\
$\mathrm{X}_{3} \mathrm{X}_{3} \mathrm{X}_{4}$ & -0.19688 & 0.198934 & -0.8080 & 0.433602 \\
$\mathrm{X}_{4}{ }^{2}$ & -0.51562 & 0.243643 & -2.1163 & 0.054183 \\
& -3.38385 & 0.243643 & -17.0100 & 0.000000 \\
\end{tabular}

$\mathrm{R}^{2}=0.9970 ;$ adjusted $\mathrm{R}^{2}=0.9933 ; \mathrm{R}=0.9984$

Table 6: Analysis of variance for the second-order polynomial model

\begin{tabular}{|l|c|c|c|c|c|}
\hline Source & Sum of squares & Degrees of freedom & Mean square & F-value & $\boldsymbol{p}>$ F \\
\hline Model & 3853.152 & 9 & 428.1280 & 323.7185 & 0.0000 \\
Residual & 23.806 & 18 & 1.3225 & & \\
Lack of fit & 23.156 & 15 & 1.544 & 7.125 & 0.06574 \\
Pure error & 0.650 & 3 & 0.217 & & \\
Total & 3876.957 & 27 & & & \\
\hline
\end{tabular}

$\mathrm{R}^{2}=0.9938 ;$ Adj $\mathrm{R}^{2}=0.9907 ; \mathrm{R}=0.9969$

ANOVA of the quadratic regression model demonstrates that the model is highly significant, which is evident from the $F$-test ( $F$ model, the ratio of mean square regression to mean square residual is 323.7185), and has a very low probability value $\left[\left(p_{\text {model }}>F\right)=0.0000\right]$. The fit of the model was checked by the coefficient of determination $\left(\mathrm{R}^{2}\right)$ and the multiple correlation coefficient $(\mathrm{R})$. The $\mathrm{R}^{2}$ value (0.9938) for Eq. (4) indicates that the sample variation of $99.38 \%$ for lactic acid was attributed to the independent variables and only $0.62 \%$ of the variation cannot be explained by the model. The value of the adjusted coefficient of determination (adjusted $\mathrm{R}^{2}=0.9907$ ) is also high, which demonstrates the high significance of the model. The high $\mathrm{R}$ value (0.9969) demonstrates strong agreement between the experimental observations and predicted values. This correlation is also confirmed by the plot of predicted versus experimental values of lactic acid production in Fig. 2, as all points cluster around the diagonal line, demonstrating that no significant violations of the model were found. Moreover, the value of lack of fit for regression Eq. (4) was not significant at the 5\% level $(p>0.05)$, indicating the good predictability of the model. Fig. 3 presents a plot of residuals versus the predicted response and displays no pattern or trend, suggesting that the variance of the original observation is constant. All residuals were smaller than $2 \%$, which indicates that the model is adequate for describing lactic acid production over the experimental ranges studied.

The 3D response surface is the graphic representation of the regression equation and is plotted to understand the interaction of the variables and locate the optimal level of each variable for maximal response (Fig. 4 and Fig. 5). Each response surface and contour plotted for lactic acid production represents the different combinations of two test variables at one time while keeping the other two variables at their respective zero level. The convex response surfaces suggest that there are well-defined optimal variables.

Molasses and CSL were the dominant nutrients controlling lactic acid production (Fig. 4). Hence, a strong interaction between these nutrients for lactic acid fermentation is inevitable. However, both may cause inhibition of lactic acid production at higher concentrations due to significant carbon and nitrogen repression. As lactic acid bacteria are nutritionally fastidious and require several amino acids and vitamins for growth, it is very important to choose the right nitrogen and carbon sources. Nitrogen is necessary for the synthesis of amino acids, enzyme cofactors, some carbohydrates and other substances. The nitrogen source is a major factor of influence on the growth of Lactobacillus (Wood and Holzapfel, 1995). On the other hand, high concentrations of nitrogen can lead to cell death (De Lima et al., 2009). 


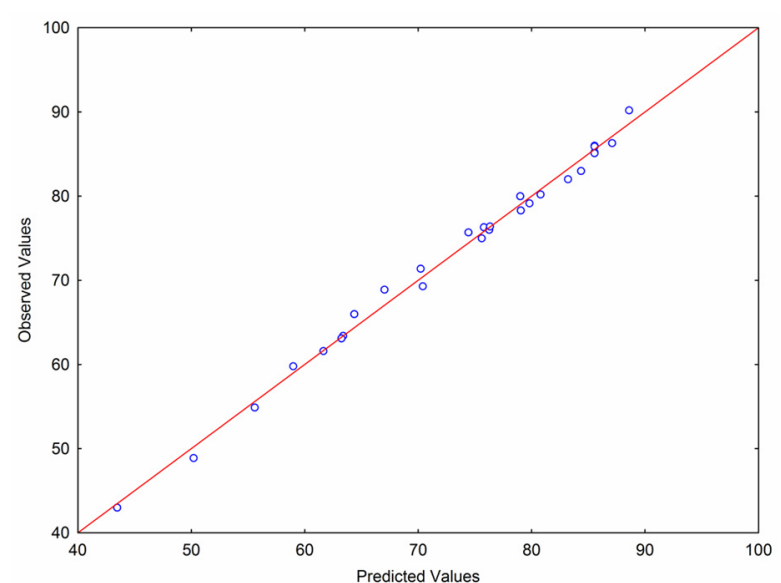

Figure 2: Plot of predicted vs. observed values of lactic acid production

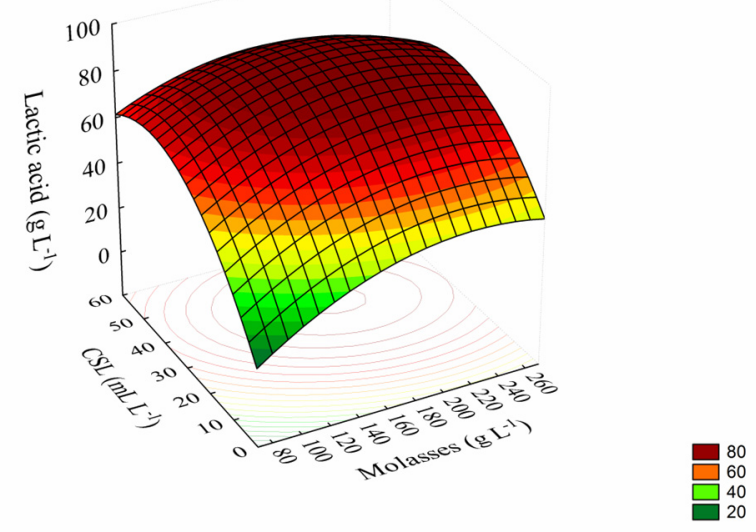

Figure 4: Response surface and contour plots of lactic acid production by L. plantarum LMISM6 showing the interaction between molasses and CSL at constant levels of $\mathrm{K}_{2} \mathrm{HPO}_{4}\left(2 \mathrm{~g} \mathrm{~L}^{-1}\right)$ and Tween $80\left(1 \mathrm{~mL} \mathrm{~L}^{-1}\right)$

CSL has long proven to be an inexpensive alternative to materials such as yeast extract (YE) and peptone (Liggett and Koffler, 1948). The use of a cheap nitrogen source for the complete replacement of YE has been widely discussed. Supplementation with whey containing lactose at 55 $\mathrm{g} / \mathrm{L}$ and $5 \%$ malt reaches a lactic acid yield similar to YE supplementation at around $55 \mathrm{~h}$ (Pauli and Fitzpatrick, 2002). Yu et al. (2008) found that CSL not only replaces $\mathrm{YE}$ as the sole nitrogen source in an optimized medium, but also helps to enhance lactic acid production when associated with other beneficial medium components.

The effect of molasses and CSL on lactic acid production was positive, as molasses is rich in trace elements and vitamins (Beaulieu et al., 1995). Yu et al. (2008) reported the same for $\mathrm{L}(+)$ lactic acid

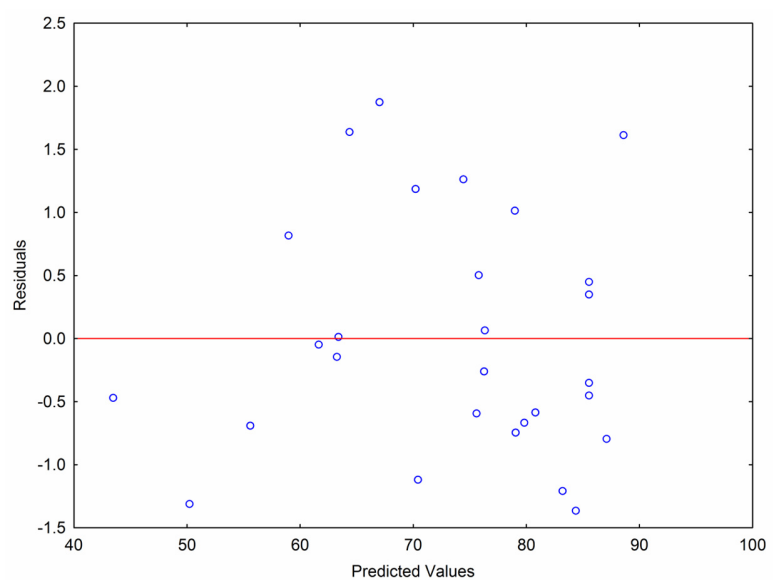

Figure 3: Plot of residuals vs. predicted values for lactic acid production.

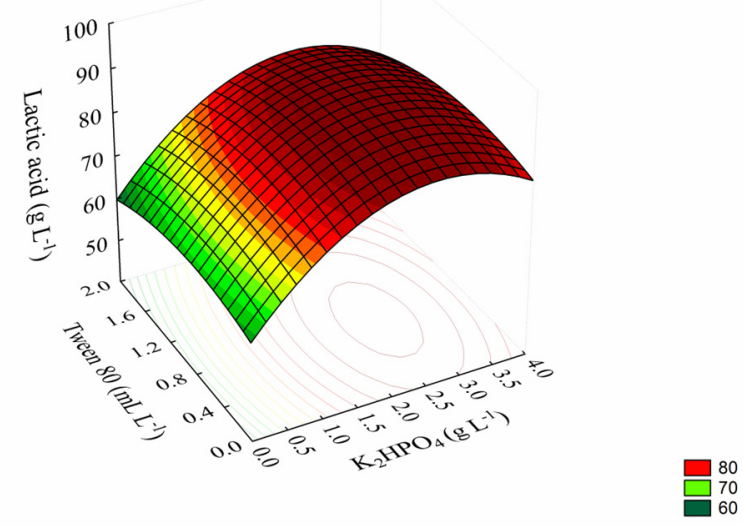

Figure 5: Response surface and contour plots of lactic acid production by L. plantarum LMISM6 showing the interaction between $\mathrm{K}_{2} \mathrm{HPO}_{4}$ and Tween 80 at constant levels of molasses $\left(170 \mathrm{~g} \mathrm{~L}^{-1}\right)$ and CSL $\left(30 \mathrm{~mL} \mathrm{~L}^{-1}\right)$

production by L. rhamnosus. The addition of phosphate to the culture medium increased lactic acid production (Fig. 5). The use of $\mathrm{K}_{2} \mathrm{HPO}_{4}$ is reported to provide $\mathrm{K}^{+}$and phosphate for microorganism growth and also acts as a buffering agent in the medium (Honorato et al., 2007). Lactic acid production increased with the increase in concentration to slightly more than $2.5 \mathrm{~g} \mathrm{~L}^{-1}$ of $\mathrm{K}_{2} \mathrm{HPO}_{4}$ and $0.8 \mathrm{~mL} \mathrm{~L}^{-1}$ of Tween 80 .

The positive effect of Tween 80 on lactic acid production is also described by Belhocine (1987), who reported that the addition of $1 \mathrm{~g} \mathrm{~L}^{-1}$ of Tween 80 significantly increased $L$. helveticus growth and lactic acid production. Yu et al. (2008) found that the addition of $1.5 \mathrm{~mL} \mathrm{~L}^{-1}$ of Tween 80 to a fermentation medium containing molasses and CSL significantly increased the production of lactic acid by 
Lactobacillus rhamnosus CGMCC 1466. This is likely due to the fact that Tween 80 can dissolve lipid structures in the cell membrane, thereby improving membrane permeability and enhancing the release of intracellular enzymes. Tween 80 has also been found to promote the migration of nutritive compounds into cells and has therefore been added to bacterial media to promote growth (Reese and Maguire, 1969). Thus, Tween 80 serves as an essential growth factor and has proven beneficial in the cultivation and fermentation of Lactobacillus (Duggan et al., 1959). However, a higher concentration of Tween $80[1.4 \%(\mathrm{w} / \mathrm{v})]$ decreased lactic acid production (Fig. 5). This was likely due to the fact that the surfactant Tween 80 becomes toxic at higher concentrations, leading to the destruction of the cell membrane and/or loss of the cell membrane function caused by the solubility of lipid bilayer (BenKun Q. et al., 2009).

The point of maximal lactic acid production was determined through canonical analysis of the adjusted model. A study was carried out to identify the nature of the stationary point (maximal point, low response or saddle point). An algorithm carried out with the Maple 9.5 program (Waterloo Maple, Inc., Canada) was used to calculate the stationary point ( $\mathrm{P} 0$ ) for the synthesis of lactic acid. These values are displayed in Table 7. The $\lambda$ values referring to molasses, $\mathrm{CSL}, \mathrm{K}_{2} \mathrm{HPO}_{4}$ and Tween 80 indicate that these responses have a maximal point, since they have equal, negative signs (Table 7). The analysis determined that the maximal predicted lactic acid concentration was $91.61 \mathrm{~g} \mathrm{~L}^{-1}$, with the corresponding optimal values of the test variables at $193.50 \mathrm{~g} \mathrm{~L}^{-1}$ of molasses, $37.50 \mathrm{~mL} \mathrm{~L}^{-1}$ of CSL, $2.65 \mathrm{~g} \mathrm{~L}^{-1}$ of $\mathrm{K}_{2} \mathrm{HPO}_{4}$ and $0.83 \mathrm{~mL} \mathrm{~L}^{-1}$ of Tween 80 .

Table 7: Stationary point for lactic acid production and coded values of the variables $X_{1}, X_{2}, X_{3}$ and $X_{4}$.

\begin{tabular}{|c|c|c|c|}
\hline $\mathbf{P}_{\mathbf{0}}$ & Lactic acid & Coordinates & Lactic acid \\
\hline$\lambda_{1}$ & -6.69 & $\mathrm{X}_{1}$ & 0.47 \\
$\lambda_{2}$ & -3.54 & $\mathrm{X}_{2}$ & 0.50 \\
$\lambda_{3}$ & -3.19 & $\mathrm{X}_{3}$ & 0.65 \\
$\lambda_{4}$ & -0.90 & $\mathrm{X}_{4}$ & 1.46 \\
\hline
\end{tabular}

All optimal points were located within the experimental region. To confirm the adequacy of the model for predicting maximal lactic acid production, three additional experiments were performed in a shaker with this optimal medium composition. The mean value of lactic acid concentration was $94.8 \mathrm{~g} \mathrm{~L}^{-1}$, which is in agreement with the predicted value of $91.61 \mathrm{~g} \mathrm{~L}^{-1}$. Thus, the model proved adequate. Yu et al. (2008) studied the addition of CSL in molasses as the sole nitrogen source and obtained $112.5 \mathrm{~g} \mathrm{~L}^{-1}$ of lactic acid in 36 hours of fermentation by Lactobacillus rhamnosus.

Plackett-Burman design was appropriate to make a preliminary assessment of the significant components $\left(\mathrm{CSL}, \mathrm{K}_{2} \mathrm{HPO}_{4}\right.$ and Tween 80 ) in the production of lactic acid. These same components were also significant by using central composite design.

\section{Comparison of the Time Course of Lactic Acid Production in the Optimized Medium Run with the Shake-Flask Method and in a Bioreactor}

The scale-up fermentation of lactic acid in the optimized medium was carried out in the bioreactor $(4 \mathrm{~L}$ of medium). The time courses are displayed in Fig. 6. After 48 hours of fermentation, lactic acid production in the bioreactor and in the shake-flask was $89.88 \mathrm{~g} \mathrm{~L}^{-1}$ and $94.8 \mathrm{~g} \mathrm{~L}^{-1}$, respectively. However, productivity in the bioreactor $\left(3.43 \mathrm{~g} \mathrm{~L}^{-1} \mathrm{~h}^{-1}\right)$ was higher than that achieved with the shake-flask method $\left(2.89 \mathrm{~g} \mathrm{~L}^{-1} \mathrm{~h}^{-1}\right)$ after $12 \mathrm{~h}$ of fermentation. Yu et al. (2008) state that this is due to the addition of different neutralizing agents.

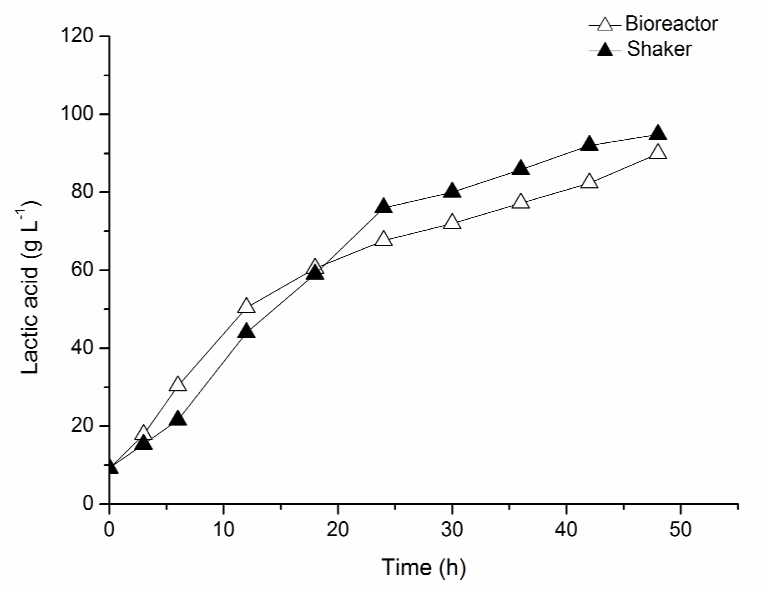

Figure 6: Time course of lactic acid production in the shaker compared to that in the bioreactor: in the shaker: $(\Delta)$; in the bioreactor $(\Delta)$.

Molasses is an economically feasible raw material for industrial production of lactic acid and it has enough necessary nutrients for growth of Lactobacillus plantarum LMISM6. However, it is important to note that the quality of molasses depends on the maturity of the sugar cane or sugar beet, the amount of sugar extracted, and the method of extraction. The fermentable sugar content of molasses varies inversely with the purity of the raw sugar produced at the factory (Gopal and Kammen, 2009). Consequently, molasses is subject to a large batch-to-batch variation that could influence the lactic acid production. 


\section{CONCLUSIONS}

Under optimized conditions, the best result for lactic acid production $\left(94.8 \mathrm{~g} \mathrm{~L}^{-1}\right)$ was obtained after 48 hours with $193.50 \mathrm{~g} \mathrm{~L}^{-1}$ of molasses, $37.50 \mathrm{~mL} \mathrm{~L}^{-1}$ of CSL, $2.65 \mathrm{~g} \mathrm{~L}^{-1} \mathrm{~K}_{2} \mathrm{HPO}_{4}$ and $0.83 \mathrm{~mL} \mathrm{~L}^{-1}$ of Tween 80. Thus, the use of molasses for fermentation by L. plantarum LMISM6 is feasible and yields considerable lactic acid production, requiring only supplementation with a cheap nitrogen source (CSL), $\mathrm{K}_{2} \mathrm{HPO}_{4}$ and Tween 80. This work focused on high titers; however in both, shaker and bioreactor, approximately one fourth $\left(50 \mathrm{~g} \mathrm{~L}^{-1}\right)$ of the sugar added initially was not utilized. Future studies that consider high conversion of sugar into final product as well as high volumetric productivity are necessary to improve the fermentation process and to reduce the downstream costs.

\section{ACKNOWLEDGMENTS}

The authors thank Plaza S.A. and Corn Products for kindly supplying the molasses and corn steep liquor, respectively, and the Brazilian funding agency Fundação de Amparo a Pesquisa do Estado de São Paulo (FAPESP) for the fellowships and financial support.

\section{REFERENCES}

Beaulieu, M., Beaulieu, Y., M'elinard, J., Pandian, S. and Goulet, J., Influence of ammonium salts and cane molasses on growth of Alcaligenes eutrophux and production of polyhydroxybutyrate. Appl. Environ. Microb., 61, 165-169 (1995).

Belhocine, D., Investigations on lactose valorization by lactic acid fermentation. Ph.D. Thesis, University of Rennes I, France (1987).

Ben-Kun, Q., Ri-Sheng, Y., Min, L. and Sheng-Song, D., Effect of Tween 80 on production of lactic acid by Lactobacillus casei. Songklanakarin J. Sci. Technol., 31, 85-89 (2009).

Bustos, G., Moldes, A.B., Alonso, J. L. and Vázquez, M., Optimization of D-lactic acid production by Lactobacillus coryneformis using response surface metholodology. Food Microbiol., 21, 143-148 (2004).

Buyukkileci, A. O. and Harsa, S., Batch production of L(+) lactic acid from whey by Lactobacillus casei (NRRL B-441). J. Chem. Technol. Biotechnol., 79, 1036-1040 (2004).
Calabia, B. P. and Tokiwa, Y., Production of Dlactic acid from sugarcane molasses, sugarcane juice and sugar beet juice by Lactobacillus delbrueckii. Biotechnol. Lett., 29, 1329-1332 (2007).

Cardinal E. V. and Hedrick L. R., Microbiological assay of corn steep liquor for amino acid content. J. Biol. Chem., 172, 609-612 (1948).

Datta, R., Tsai, S. P., Bonsignor P., Moon S. and Frank J., Technological and economical potential of polylactic acid and lactic acid derivatives. FEMS Microbiol. Rev., 16, 221-231 (1995).

De Lima, C. J. B., Coelho, L. F., Blanco, K. C. and Contiero, J., Response surface optimization of D(-)-lactic acid production by Lactobacillus SMI8 using corn steep liquor and yeast autolysate as an alternative nitrogen source. Afr. J. Biotechnol., 8, 5842-5846 (2009).

Duggan, D. E., Anderon, A. W. and Ellker, P. R., A frozen concentration of Lactobacillus acidophilus for preparation of a palatable acidophilus milk. Food Technol., 13, 465-469 (1959).

Dumbrepatil, A., Adsul, M., Chaudhari, S., Khire, J. and Gokhale, D., Utilization of Molasses Sugar for Lactic Acid Production by Lactobacillus delbrueckii subsp. delbrueckii Mutant Uc-3 in Batch Fermentation. Appl. Environ. Microbiol., 74, 333-335 (2008).

Fitzpatrick, J. J. and Keeffe, U. O., Influence of whey protein hydrolyzate addition to whey permeate batch fermentations for producing lactic acid. Proc. Biochem., 37, 183-186 (2001).

Gopal, A. R. and Kammen, D. M., Molasses for ethanol: the economic and environmental impacts of a new pathway for the lifecycle greenhouse gas analysis of sugarcane ethanol. Environ. Res. Lett., 4, 1-5 (2009).

Hofvendahl, K. and Hahn-Hägerdal, B., L-Lactic acid production from whole wheat flour hydrolyzate using strains of Lactobacilli and Lactococci, Enzyme Microb. Technol., 20, 301307 (1997).

Honorato, T. L., Rabelo, M. C., Pinto, G. A. S. and Rodrigues, S., Produção de ácido lático e dextrana utilizando suco de caju como substrato. Cienc. Tecnol. Aliment., 27, 254-258 (2007).

Krishnan, S., Prapulla, S. G., Karanth, N. G., Screening and selection of media components for lactic acid production using Plackett-Burman design. Bioprocess. Eng., 19, 61-65 (1998).

Liggett, R. W. and Koffler, H., Corn steep liquor in microbiology. Microbiol. Mol. Biol., 12, 297-311 (1948). 
Lima, U.A., Aquarone, E. and Borzani, W., Biotecnologia: tecnologia das fermentações. São Paulo, Brasil (1975).

Miller, G. L., Use of dinitrossalicylic acid reagent for determination of reducing sugar. Anal. Chem., 31, 426-428 (1959).

Plackett, R. L. and Burman, J. P., The Design of Optimal Multifactorial Experiments. Biometrika, v. 33 (1946)

Ohara, H., Biorefinery. Appl. Microbiol. Biotechnol., 62, 474-477 (2003).

Pauli, T. and Fitzpatrick, J. J., Malt combing nuts as a nutrient supplement to whey permeate for producing lactic by fermentation with Lactobacillus casei. Process. Biochem., 38, 1-6 (2002).

Reddy, P. R. M., Reddy, G. and Seenayya, G., Production of thermostable beta-amylase and pullulanase by Clostridium thermosulfurogens SV2 in solid-state fermentation: screening of nutrients using Plackett-Burman design. Bioprocess. Eng., 21, 175-179 (1999).

Reese, E. T. and Maguire, A., Surfactants as stimulants of enzyme production by microorganisms, Appl. Microbiol., 17, 242-245 (1969).

Silva, S. S. and Mancilha, I. M., Aproveitamento de agroindustriais: ácido lático uma alternativa. Boletim da Sociedade Brasileira de Ciência e Tecnologia de Alimentos, 25, 37-40 (1991).

Srinivas, M. R. S., Chand, N. and Lonsane, B. K., Use of Plackett-Burman design for rapid screening of several nitrogen sources, growth/ product promoters, minerals and enzyme inducers for the production of alpha-galactosidase by Aspergillus niger MRSS 234 in solid state fermentation system. Bioprocess. Eng., 10, 139144 (1994).

Son, K-H., Hong, S-H., Kwon, Y-K., Bae, K-S., Kim, Y-K., Kwon, B-M., Kim, S-U., Bok, S-H., Production of a Ras farnesyl protein transferase inhibitor from Bacillus licheniformis using Plackett- Burman design. Biotechnol. Lett., 20, 149-151 (1998).

Stanbury, P. F., Whitaker, A., Hall, S. J., Media for industrial fermentations. In: Principles of fermentation technology. Oxford: Pergamon, $p$ 93-122 (1986).

Tejayadi, S. and Cheryan, M., Lactic acid from cheese whey permeate. Productivity and economics of a continuous membrane bioreactor. Appl. Microbiol. Biotechnol., 43, 242-248 (1995).

Wood, B. J. B. and Holzapfel, W. H., The genera of lactic acid bacteria. Glasgow: Blackie Academic and Professional (1995).

Yu, X., Hallett, S. G. and Watson, A. K., Application of the Plackett-Burman experimental design to evaluate nutritional requirements for the production of Colletotrichum coccodes spores. Appl. Environ. Microbiol., 47, 301- 305 (1997).

Yu, L., Lei, T., Ren, X., Pei, X. and Feng, X., Response surface optimization of 1-(+)-lactic acid production using corn steep liquor as an alternative nitrogen source by Lactobacillus rhamnosus CGMCC 1466. Biochem. Eng. J., 39, 496-502 (2008).

Zhou, S., Shanmugam, K. T., Yomano, L. P., Grabar, T. B. and Ingram L. O., Fermentation of $12 \%$ (w/v) glucose to $1.2 \mathrm{M}$ lactate by Escherichia coli strain SZ194 using mineral salts medium. Biotechnol. Lett., 28, 663-670 (2006). 